Інноватика у вихованні. Випуск 11. Том 1. 2020.

УДК: 378

DOI: $10.35619 /$ iiu.v1i11.236

Потапчук Тетяна

доктор педагогічних наук, професор, професор кафедри теорії та методики дошкільної і спеціальної освіти ДВНЗ «Прикарпатський національний університет імені Василя Стефаника»,

м. Івано-Франківськ, Україна ORCID: 0000-0003-1680-6976 e-mail: tatvolod@ukr.net

\title{
ПРОФЕСІЙНА ПІДГОТОВКА МАЙБУТНЬОГО ФАХІВЦЯ 3 ІНФОРМАЦІЙНО-КОМУНІКАТИВНИХ ТЕХНОЛОГІЙ У ЗАКЛАДІ ВИЩОЇ ОСВІТИ
}

\begin{abstract}
Анотація. Стаття присвячена проблемі професійної підготовки майбутнього фахівця 3 інформаційно-комунікативних технологій у закладі вищої освіти. Зазначено, що у закладі вищої освіти майбутній фахівець повинен оволодіти не тільки базовими професійними знаннями й уміннями, а й ціннісними орієнтаціями спеціаліста, відповідним стилем взаємин з людьми та колегами, комунікаційною та інформаційною культурою, уміти мотивувати свою діяльність, бути здатним до розвитку свого творчого потенціалу у професійній сфері.

Наголошено, що організація професійної підготовки майбутнього фахівця з IКТ у ЗВО передбачає використання таких інформаційно-комунікаційних технологій: ознайомлення 3 сучасними методами та технологіями обробки інформації, врахування специфіки організації інформаційних процесів у професійному середовищі майбутнього фахівця.

У сучасних умовах феномен професійна компетентність майбутнього фахівця з IКТ у педагогічній теорії і практиці набув актуальності. Незворотні зміни в житті, зумовлені інформаційним розвитком суспільством, внесли корективи в сутнісні характеристики поняття «професійна компетентність майбутнього фахівця з ІКТ». Зза умови збереження свого соціокультурного, морального потенціалу професійна компетентність інтегрується у систему економічних відносин, отже освіта стає економічною категорією. У цьому значенні компетенції перегукуються з метою освіти. 3 одного боку, компетенція - це дрібне ділення узагальнених цілей освіти та більш високий рівень конкретизації, а з іншого боку, це діяльнісна складова здобутої освіти, яка допомагає проявитися (виявити) знання, уміння й навички в незнайомій ситуації, тобто $є$ більш високим рівнем узагальнення останніх.

Ключові слова: професійна підготовка, майбутній фахівець з інформаційнокомунікативних технологій, заклад вищої освіти, принципи забезпечення якості професійної підготовки.
\end{abstract}

Постановка проблеми. Дослідження сучасного стану інформатизації вищої освіти, засвідчує, що інформаційно-комунікативні технології (ІКТ) виступають засобом розвитку професійної підготовки майбутнього фахівця у закладі вищої освіти.

Інформаційно-комунікаційне навчальне середовище закладу вищої освіти розглядається нами як засіб професійної підготовки майбутніх фахівців з IКТ, 
передбачає комплексне використання інформаційно-комунікаційних технологій безпосередньо в навчальному процесі, науково-дослідній роботі, в організації професійної підготовки, іiі педагогічному моніторингу та позиціонується нами як педагогічна система, орієнтована на вирішення завдань професійної підготовки майбутнього фахівця та формування його професійної компетентності.

Аналіз останніх досліджень 3 проблеми. У психолого-педагогічних дослідженнях існує досить усталена точка зору, згідно якої поняття «компетентність» включає знання, вміння, навички здійснення педагогічної діяльності (Л. П. Максимова, В. А. Петрук, А. В. Хуторской та ін). В структуру професійної компетентності сучасні дослідники включають комунікативну компетентність. Розуміння цього сучасного феномена у дослідженні відповідає науковому опису його характеристик у працях С. Братченка: «...шана і уважність до співрозмовника, неупереджена зацікавленість, здатність встановлювати контакт 3 дорослими і дітьми); здатність слухати і чути; емпатія; мистецтво допомогти співрозмовнику у висловленні своєї думки; здатність адекватно виражати власну позицію; комунікативна гнучкість і конструктивність, готовність вирішувати міжособистісні проблеми; здатність працювати в «команді» (Братченко, 2006, c.143).

Використання операційного підходу до результатів педагогічної діяльності визначило місце компетенцій в освітньому процесі. У цьому значенні компетенції перегукуються з метою освіти, але ця мета формальна, операційно перевіряється. 3 одного боку, компетенція - більш дрібне ділення узагальнених цілей освіти та більш високий рівень конкретизації, з іншого боку, це діяльнісна складова здобутої освіти, яка допомагає проявитися (виявити) знання, уміння й навички в незнайомій ситуації, тобто є більш високим рівнем узагальнення останніх. У цьому зв'язку слід звернути увагу на те, що компетенція $\epsilon$ важливою педагогічною умовою досягнення мети освіти, оскільки завдяки їй студент виступає в якості активного носія суб'єктивного досвіду (Шепель, 2001, с. 96).

Мета статті - теоретично обгрунтувати професійну підготовку майбутнього фахівця з інформаційно-комунікативних технологій у закладі вищої освіти.

Виклад основного матеріалу дослідження. Компетенція не зводиться до підсумовування знань і умінь, оскільки значною мірою вона залежіть від умов, в т.ч. педагогічних. Володіти сукупністю компетенцій, необхідних для успішної інтеграції в сучасному соціумі, значить уміти мобілізувати в практичній діяльності здобуті знання і набутий досвід. Компетенція тісно пов'язана з мобілізацією знань, умінь і поведінкових реакцій, залежно від умов конкретної діяльності. Загальні компетенції визначають сутність усіх професійних видів діяльності. Ядро загальних компетенцій утворюють адаптація, соціалізація, інтеграція в соціум і самореалізація особистості. Освіта перестає бути лише передавальним механізмом культури, більшою мірою вона стає механізмом іiі породження. У цьому зв'язку траєкторію розвитку освітніх процесів у новій соціокультурній ситуації можна сформулювати у такий спосіб: досягти якісно нового рівня підготовки молодого фахівця можна за рахунок розвитку іiі загальних компетенцій на основі гармонійного розвитку взаємопов'язаних систем: Людина - Соціум - Природа.

Згідно поглядів В. Агапова і С. Шишова (2001, с. 8-19) загальні компетенції можна представити як поетапне досягнення людиною вищого освітнього рівня:

- досягнення елементарної і функціональної грамотності, коли на доступному, мінімально необхідному рівні формуються первинні знання, світоглядні та поведінкові якості особистості, необхідні для подальшої освіти; 
- досягнення загальної освіти, коли людина набуває необхідні й достатні знання про навколишній світ й опановує його найзагальнішими способами діяльності, спрямованими на пізнання й перетворення тих чи інших об'єктів дійсності;

- розвиток загальних компетенцій, пов'язаних із формуванням на базі загальної освіти таких значущих для особистості й суспільства якостей, які дозволяють людині якомога повніше реалізувати себе в конкретних видах трудової діяльності, що відповідають суспільно необхідному поділу праці і ринковим механізмам стимулювання найбільш продуктивного i конкурентоспроможного функціонування працівника тієї чи іншої кваліфікації та профілю;

- оволодіння культурою, коли людина не тільки усвідомлює матеріальні та духовні цінності, створені попередніми поколіннями, але й здатна адекватно оцінювати свою особисту участь у розвитку суспільства, здійснювати свій внесок у безперервний культуротворчий процес як власного соціуму, так і цивілізації в цілому;

- формування індивідуального менталітету особистості, тобто тих усталених, глибинних підвалин світосприйняття, світогляду й поведінки людини, які роблять iii унікальною, неповторною у поєднанні 3 відкритістю для безперервного збагачення особистих ментальних цінностей i здатністю до всебічної самореалізації в духовному просторі людства.

Основою професійної компетентності є так звані ключові компетентності, до яких А. Хуторськой відносить: ціннісно-смислову, загальнокультурну, навчальнопізнавальну, інформаційну, комунікативну, соціально-трудову, особистісне самовдосконалення (Хуторской, 2003).

Враховуючи наукові позиції вчених щодо визначення поняття «професійна компетентність», доходимо висновку, що ключовими професійними компетентностями майбутнього фахівця з ІКТ є:

- особистісно-індивідуальна компетентність - відображає професійноспрямовані переконання, цінності, потреби, вольові риси особистості, мотиви професійної діяльності, уміння досягати поставленої мети при виконанні професійних завдань;

- предметно-практична компетентність - передбачає володіння системою фундаментальних знань класичних наук, соціальних законів; способами прийняття рішень; операційними знаннями, уміннями i навичками для виконання функціональних обов'язків; глибоке знання нормативної та правової бази, галузевих стандартів; сформованість умінь застосовувати ці знання на практиці;

- інформаційна компетентність (ІКТ-компетентності) - пов'язана із системою знань й умінь, за допомогою яких засобами інформаційно-комунікативних технологій фахівець може самостійно здійснювати пошук, аналіз, відбір, обробку та передачу інформації для особистих, професійних і навчальних цілей;

- управлінська компетентність - включає систему знань з основ теорії управління; сформованість уміння планувати, формувати цілі й завдання діяльності, організовувати діяльність та здійснювати іiі аналіз; виокремлення та формулювання проблемних аспектів професійної діяльності; впровадження прогресивних форм і методів професійної діяльності;

- пізнавальна компетентність - відображає систему знань й умінь пізнавальної діяльності; сформованість умінь цілепокладання, самостійної навчально-пізнавальної діяльності, самооцінки; уміння створювати, опановувати і використовувати інновації у професійній діяльності; 
- комунікативна компетентність - пов'язана із знаннями й уміннями взаємодіяти 3 оточуючими людьми, сформованістю уміння професійно спілкуватися та працювати в групі (Competency-based training, 2003).

За умов реалізації компетентнісного підходу у вищій освіті інтегрованим показником якості професійної підготовки майбутніх фахівців $є$ рівень сформованості професійної компетентності, який піддається вимірюванню.

Наприклад, В. Шепель до визначення компетентності включає знання, розуміння, досвід, теоретико-прикладну підготовленість до використання знань (Шепель, 2001). Інші наявні в педагогіці визначення компетентності не суперечать цьому, але в той же час не повною мірою відображають його суть. Наприклад, деякі дослідники наголошують про потенційну готовність вирішувати завдання із знанням справи, але не розкривають змісту такої готовності. Під компетентністю розуміють поглиблене знання, стан адекватного виконання завдання, здатність до актуального виконання діяльності (Шишов и Агапов, 2001, с. 12).

Специфіка педагогічних цілей $з$ розвитку загальних компетенцій полягає в тому, що вони формуються у вигляді дій викладача. В системі вищої школи слід формувати здатність майбутнього фахівця самостійно управляти своєю діяльністю, самим собою. Зрозуміло, що таке самоврядування може відбутися за умови, якщо буде сформована:

1) понятійна основа (формування знань і розуміння навколишньої дійсності);

2) емоційно-ціннісна основа (формування ставлень особистості до навколишнього світу та інших людей);

3) операційна основа (формування вміння співпрацювати 3 об'єктами навколишньої дійсності).

Проаналізуємо структуру професійної компетентності майбутнього фахівця 3 IКТ. Наприклад, Г. Хайдеггер структурує компетентність за такими вимірами: когнітивний (знання фактів, розуміння, тематичне судження), нормативний (абсолютна оцінка, оцінка залежно від ситуації та матеріалу), діяльнісний (планування, підготовка засобів, виконання й перевірка) (Heidegger, 1996, с. 110).

Складовими компонентами професійної компетентності майбутніх фахівців 3 IKT, на думку В. Петрук, є: пізнавальний, ціннісно-орієнтаційний і настановчоповедінковий (Петрук, 2008).

Дослідниця А.Бусигіна визначає у ii структурі такі складові: професійнозмістовний (базовий компонент, передбачає наявність теоретичних знань у межах фаху, що забезпечує усвідомлення змісту професійної діяльності); професійнодіяльнісний (практичний компонент, включає професійні знання і вміння, випробувані в дії, засвоєні особистістю як найефективніші); професійноособистісний компонент (включає професійно-особистісні якості фахівця як особистості, індивіда та суб'єкта діяльност) і (Бусигіна, 2003).

Г. Безюльова структуру професійної компетентності розглядає у єдності трьох компонентів: мотиваційно-ціннісного, предметно-практичного та саморегулятивно-вольового, які розподіляються за: видами професійної діяльності (функціональна, правова, економічна, технічна, комунікативна); соціально значущими якостями особистості, iіi властивостями й особливостями особистості (пізнавальна, рефлексивна); професійною спрямованістю особистості (мотиваційна) (Безюльова, 2009).

Висновки і перспективи подальших розвідок. Отже, до найбільш значущих принципів забезпечення якості професійної підготовки майбутніх фахівців з ІКТ відносимо: принципи державної політики в галузі освіти, принципи організації професійної підготовки, принципи навчання. 
Принципи державної політики в галузі освіти - це основні положення, на яких грунтується політика держави у даній сфері (вони визначені у статті 6 Закону України «Про освіту» (2011)). У контексті дослідження виокремлюємо такі принципи: неперервності, регіоналізації, фундаменталізації, гуманізації.

До принципів організації професійної підготовки відносимо ті, які сприяють активізації пізнавальної діяльності майбутніх фахівців з IКТ, а саме: принцип підтримуючої мотивації, проблемності, відповідності навчально-пізнавальної діяльності характеру практичних завдань, поєднання індивідуальних і колективних форм навчання.

Отже, реалізація професійної підготовки майбутніх фахівців з ІКТ у вищій школі, що грунтується на означених принципах, дозволить, на нашу думку: 1) організувати навчальну діяльність, у процесі якої за допомогою системи методів, форм та новітніх інформаційних технологій послідовно моделюватиметься предметний зміст діяльності майбутнього фахівця із максимальним ступенем індивідуалізації; 2) сформувати позитивну мотивацію до оволодіння студентами професійними знаннями, розвинути їх пізнавальну активність, уміння застосовувати новітні інформаційно-комунікативні технології у майбутній професійній діяльності; 3) розвинути практичні уміння та навички вирішення інформаційних задач, які визначаються напрямами професійної діяльності та забезпечують швидку адаптацію на робочому місці; 4) набути досвіду самостійно оволодівати знаннями, вирішувати професійні проблеми, розвивати навички самостійного прийняття рішень на основі отриманого досвіду та спілкування у професійному середовищі.

Вважаємо, що зазначене вище є характерними ознаками якісної професійної підготовки майбутніх фахівців з ІКТ у ЗВО.

Перспективи подальших досліджень вбачаємо в обгрунтуванні форм і методів формування професійної компетентності майбутнього фахівця з IКТ у закладі вищої освіти.

\section{СПИСОК ВИКОРИСТАНИХ ДЖЕРЕЛ}

Братченко, С. (2001). Гуманитарная экспертиза образования: условия проведения. Школьные технологии. Вып.4. С. 137-149.

Шепель, В. (2001). Человековедческие технологии: сущность и перспективы. Мир образования - образование в мире. Вып.4. С. 94-105.

Шишов, С., Агапов, И. (2001). Компетентностный подход к образованию как необходимость. Мир образования - образование в мире. 4. С. 8-19.

Хуторской, А. В. (2003) Ключевые компетенции. Технология конструирования. Народное образование. № 5. С. 55-61.

Competency-based training. Compilation of seminar subject matter: Training the trainers (2003). URL: http://starwww. inwent.org/starweb/inwentdocs/Lehrbrief_01_engl.pdf. [Accessed 12/04/20]

Heidegge, G. (1996). Von Schlusse- qualifikationen zu Schlusselk ompetenzen. Schlssel qualifikationen kontrovers. Aargau. 158 p.

Петрук, В. (2008). Теоретико-методичні засади формування базових професійних компетентностей у майбутніх фахівців технічних спеціальностей. Доктор педагогічних наук. Національний педагогічний університет імені М. П. Драгоманова.

Бусыгина, А. (2003). Профессор - профессия: теория проектирования содержания образования преподавателя вуза. 2-е изд., испр. и доп. Самара: Изд. СамСПУ, 198 с. 
Безюлёва, Г. (2008). Психолого-педагогическое сопровождение профессиональной адаптащии учащихся и студентов: монография. Москва: НОУ ВПО Московский психолого-социальный институт. 320 с.

Наконечна, О. (2012). Формування професійної компетентності майбутніх фахівиів з обліку та аудиту у вищих аграрних навчальних закладах. Кандидат педагогічних наук. Нац. акад. пед. наук України, Ін-т вищ. освіти.

Про освіту: Закон України від 23.05.1991 № 1060-XII в редакції від 01.01.2015. URL: http://zakon4.rada.gov.ua/laws/show/1060-12. [Дата звернення 12.04.230p.].

\section{REFERENCES}

Bratchenko, S. (2001). Gumanitarnaya ekspertiza obrazovaniya: usloviya provedeniya [Humanitarian Expertise of education: conditions to organize]. School technologies Shkolnye tekhnologii. Vyp.4. S. 137-149. (in Russian)

Shepel, V. (2001). Chelovekovedcheskie tekhnologii: sushchnost i perspektivy [Human-science technologies: essence and prospects]. Mir obrazovaniya - obrazovanie v mire. Vyp.4. S. 94-105. (in Russian)

Shishov, S., Agapov, I. (2001). Kompetentnostnyi podkhod k obrazovaniyu kak neobkhodimost [Competency Approach to Education as a Necessity]. Mir obrazovaniya - obrazovanie v mire. No 4. S. 8-19. (in Russian)

Khutorskoi, A. (2003) Klyuchevye kompetentsii. Tekhnologiya konstruirovaniya [Key competencies. Design technology]. Narodnoe obrazovanie. No 5. S. 55-61. (in Russian)

Competency-based training. Compilation of seminar subject matter: Training the trainers (2003). URL : inwent.org/starweb/inwentdocs/Lehrbrief_01_engl.pdf. [Accessed 12/04/20]

Heidegge, G. (1996). Von Schlussel qualifikationen zu Schlussel kompetenzen. Schlussel qualifikationen kontrovers. Aargau. 158 r. (in German)

Petruk, V. (2008). Teoretyko-metodychni zasady formuvannia bazovykh profesiinykh kompetentnostei u maibutnikh fakhivtsiv tekhnichnykh spetsialnostei [Theoretical and Methodological Principles of Formation of Basic Professional Competences in the Future Specialists of Technical Specialties]. Doktor pedahohichnykh nauk. Natsionalnyi pedahohichnyi universytet imeni M.P. Drahomanova. (in Ukrainian)

Busygina, A. (2003). [Professor - professiya: teoriya proektirovaniya soderzhaniya obrazovaniya prepodavatelya vuza. Professor - Profession: Theory of Designing the Content of Education of a University Teacher]. 2-e izd., ispr. i dop. Samara: Izd. SamSPU, 198 s. (in Russian)

Bezyuleva, G. (2008). Psikhologo-pedagogicheskoe soprovozhdenie professionalnoi adaptatsii uchashchikhsya i studentov: monografiya. [Psychological and Pedagogical Support for Professional Adaptation of Schoolchildren and Students: monograph]. Moskva: NOU VPO Moskovskii psikhologo-sotsialnyi institut. 320 s. (in Russian)

Nakonechna, O. (2012). Formuvannia profesiinoi kompetentnosti maibutnikh fakhivtsiv z obliku ta audytu u vyshchykh ahrarnykh navchalnykh zakladakh [Formation of Professional Competence of Future Specialists in Accounting and Auditing in Higher Agricultural Educational Institutions]. Kandydat pedahohichnykh nauk. Nats. akad. ped. nauk Ukrainy, In-t vyshch. osvity. Kyiv, 2014. (in Ukrainian)

Pro osvitu [On education ]: Zakon Ukrainy vid 23.05.1991 № 1060-XII v redaktsii vid 01.01.2015. URL: http://zakon4.rada.gov.ua/laws/show/1060-12. [Accessed $12 / 04 / 20$ ] (in Ukrainian) 


\title{
IN INFORMATION AND COMMUNICATION TECHNOLOGIES IN THE HIGHER EDUCATION INSTITUTION
}

\author{
Tetiana Potapchuk \\ Doctor of Sciences (in Pedagogy), Professor, \\ Professor at the Department of Theory and \\ Methods of Preschool and Special Education, \\ SHEI "Vasyl Stefanyk Prykarpattia National University", \\ Ivano-Frankivsk, Ukraine \\ ORCID: 0000-0003-1680-6976 \\ e-mail:tatvolod@ukr.net
}

\begin{abstract}
Abstract. The article is devoted to the issue of professional training of future specialists in information and communication technologies in higher education.

It is stated that in a higher education institution the future specialist have to master not only basic professional knowledge and skills, but also with value orientations of the specialist, the appropriate style of relationships with people and colleagues, communication and information culture, be able to motivate their activities, be able to develop their creative potential in the professional sphere.

It is emphasized that the organization of professional training of future ICT specialists in institution of higher education provides for the use of such information and communication technologies: learning modern methods and technologies of information processing, taking into account the specifics of information processes in the professional environment of future specialists.

In modern conditions, the phenomenon of professional competence of the future specialist in ICT in pedagogical theory and practice has become relevant. Irreversible changes in life, due to the information development of society, have made adjustments to the essential characteristics of the concept of "professional competence of the future ICT specialist"; provided that the preservation of its socio-cultural, moral potential, professional competence is integrated into the system of economic relations, so education becomes an economic category. In this sense, competencies resonate for the purpose of education, but this goal is formal, operationally verified. On the one hand, competence is a smaller division of the generalized goals of education and a higher level of concretization, and on the other hand, it is an activity component of the received education which helps to be shown (to reveal) knowledge, abilities and skills in an unfamiliar situation, that is a higher level of generalization of the last.
\end{abstract}

Key words: professional training, future specialist in information and communication technologies, institution of higher education, principles of quality assurance of professional training.

Стаття надійшла до редакиії 27. 04. 2020. p. 